\title{
Oropharyngeal dysphagia and its psychiatric comorbidities
}

Citation for published version (APA):

Verdonschot, RJCG. (2018). Oropharyngeal dysphagia and its psychiatric comorbidities: the prevalence of affective symptoms and the unmet clinical need for integrated care in medically unexplained symptoms. [Doctoral Thesis, Maastricht University]. Maastricht University. https://doi.org/10.26481/dis.20181115rv

Document status and date:

Published: 01/01/2018

DOI:

10.26481/dis.20181115rv

Document Version:

Publisher's PDF, also known as Version of record

\section{Please check the document version of this publication:}

- A submitted manuscript is the version of the article upon submission and before peer-review. There can be important differences between the submitted version and the official published version of record.

People interested in the research are advised to contact the author for the final version of the publication, or visit the DOI to the publisher's website.

- The final author version and the galley proof are versions of the publication after peer review.

- The final published version features the final layout of the paper including the volume, issue and page numbers.

Link to publication

\footnotetext{
General rights Owners
rights.

- You may freely distribute the URL identifying the publication in the public portal. please follow below link for the End User Agreement:

www.umlib.nl/taverne-license

Take down policy

If you believe that this document breaches copyright please contact us at:

repository@maastrichtuniversity.nl

providing details and we will investigate your claim.
}

Copyright and moral rights for the publications made accessible in the public portal are retained by the authors and/or other copyright owners and it is a condition of accessing publications that users recognise and abide by the legal requirements associated with these

- Users may download and print one copy of any publication from the public portal for the purpose of private study or research.

- You may not further distribute the material or use it for any profit-making activity or commercial gain

If the publication is distributed under the terms of Article $25 \mathrm{fa}$ of the Dutch Copyright Act, indicated by the "Taverne" license above, 
Summary 



\section{Summary}

This thesis reports our research on clinically relevant affective symptoms in patients with oropharyngeal dysphagia (OD), and it consists of two sections. Chapters 2, 3, and 4 discuss clinically relevant affective symptoms in dysphagic patients with an underlying somatic disease. Chapters 5 and 6 discuss psychiatric comorbidities in patients with medically unexplained oropharyngeal and otorhinolaryngological symptoms.

\section{Prevalence of affective symptoms in patients with OD}

Patients with somatic disease often suffer from psychiatric problems. For example, affective symptoms are common in cardiac patients, patients with chronic obstructive pulmonary disease, and patients with diabetes. The prevalence of clinically relevant affective symptoms varies with the etiology of the somatic disease. Before starting on this thesis, we knew little about affective symptoms and psychiatric comorbidity in patients with OD. However, these patients often exhibited a depressed mood during their outpatient clinic visit or behaved anxiously during the interview and physical examination.

The goal of the first study, as presented in Chapter 2, was to determine the prevalence of clinically relevant affective symptoms in the population of outpatient clinic patients with OD. All of the 96 included patients had OD, as assessed with Fiberoptic Endoscopic Evaluation of Swallowing (FEES) and Videofluoroscopy of Swallowing (VFS), and were diagnosed with an underlying somatic cause of OD (Parkinson's disease, head and neck cancer, myotonic dystrophy, etc.). The Hospital Anxiety and Depression Scale (HADS) was used for measuring clinically relevant symptoms of anxiety and depression. This validated questionnaire consists of 14 items: 7 on the anxiety subscale and 7 on the depression subscale. Every item is scored from 0 to 3, resulting in a range from 0 to 21 on each subscale. Symptoms of anxiety or depression were defined as clinically relevant when they received a score of 8 or more. In addition, the study used a visual analogue scale (VAS), namely the simple and highly subjective Dysphagia Severity Scale (DSS), to elicit a patient's own evaluation of the current swallowing status. This study showed a prevalence of $47.3 \%(\mathrm{~N}=43)$ of clinically relevant affective symptoms in OD patients, which was in line with many other outpatient populations and underlined the significant psychological burden of OD. Furthermore, patients with clinically relevant symptoms of anxiety scored significantly lower on the DSS compared to patients without symptoms of anxiety. This indicated either that symptoms of anxiety might lead to more subjective dysphagic complaints, or that OD might be a risk factor for having clinically relevant symptoms of anxiety. No significant association was found between the DSS scores and clinically relevant symptoms of depression. 


\section{Severity of OD and affective symptoms}

As mentioned above, clinically relevant affective symptoms are frequently present in patients with OD. We expected to find that patients with severe OD had a higher risk of exhibiting clinically relevant affective symptoms compared to patients with mild or moderate OD.

In chapter 3 the relationship between the severity of OD and clinically relevant affective symptoms was investigated. In total 107 patients with OD were included in the study, all of whom were diagnosed with an underlying somatic cause of OD. They underwent a standardized FEES examination whereby the severity of OD was measured using four visuoperceptual FEES variables, which were scored by two independent consultants. These judges were blinded for each other's ratings and for the patients' history. For measurement of clinically relevant anxiety and depression symptoms, the patients had to fill out the HADS. The DSS was used for the patient's own evaluation of their swallowing status. Although a positive association between HADS scores and FEES outcome variables was expected, no such relationship was found. For some FEES variables, a negative association was found. Apparently, patients with more severe OD did not exhibit clinically relevant affective symptoms more often. Hence, the presence of clinically relevant affective symptoms in OD patients cannot be inferred from the severity of the swallowing impairment as measured with FEES. Moreover, the DSS result was not associated with any of the FEES outcome variables, meaning no relationship was found between the measured severity of OD and the patients' own subjective evaluation of swallowing impairment. Sensory deficits in patients with a neurological disease, and thereby presumably with a less accurate perception of swallowing problems, might be an explanation (severe $O D$, but few complaints). In chapter $\mathbf{2}$ we already reported that the DSS outcome was associated with clinically relevant symptoms of anxiety. Perhaps higher levels of anxiety (and possibly also depression) might influence the perception of swallowing impairment, leading the patients to overestimate their swallowing problem. In other words, anxiety may amplify the subjective perception of swallowing problems (i.e., alarm falsification).

\section{Evaluation of affective symptoms in OD}

Chapter 4 presented an overview of the published literature on anxiety and depression in OD patients based on a systematic literature review. After a structured database search in Embase, Medline, Web-of-Science, PsycINFO, Cochrane Library, and Google Scholar, 24 articles were included for analysis. The included studies were assessed for methodological quality using a 12-item critical appraisal tool with which two independent reviewers evaluated the internal and external validity. None of the studies fulfilled all the criteria for methodological quality. Because of the heterogeneous outcomes and methodological limitations, data could not be pooled. Although no metaanalytic conclusions could be drawn, some trends were observed. All 24 studies concluded that depression was significantly and positively associated with impaired 
swallowing function. Nine out of the 12 studies investigating anxiety concluded that clinically relevant anxiety symptoms were positively associated with swallowing problems. However, it remained unclear if there is a causal relationship. Therefore, future cohort studies should use standardized instrumental measurement tools for $O D$, and psychiatric assessment should be done by a psychiatrist as a gold standard instead of relying on self-reporting questionnaires in order to diagnose the presence and severity of the affective condition. Just 5 of the included studies used FEES or VFS to measure OD, and our own study (chapter 3) was the only one among these that described the measured outcome variables.

\section{Medically unexplained OD}

Sometimes, though rarely, patients have complaints of OD without demonstrable abnormalities in the anatomy of the upper aero-digestive tract and/or swallowing physiology. This medically unexplained oropharyngeal dysphagia (MUNOD) is a difficult problem for healthcare professionals.

The study in chapter 5 investigated clinically relevant affective symptoms in 14 patients with MUNOD. The HADS was used to measure the presence of clinically relevant affective symptoms, and the DSS was used for the patient's own evaluation of swallowing. None of the included patients showed any structural and/or physiological abnormalities or any significant swallowing problems during a standardized FEES examination. Five visuoperceptual FEES variables were scored by two independent judges. Most patients showed abnormal piecemeal deglutition (sequential swallowing on the same bolus). This could be a MUNOD symptom because multiple swallows of smaller fragments of the bolus as part of a behavioral adaptation might give the patient a sense of security and control in an aroused status of anxiety. More patients $(42.8 \%$, $\mathrm{N}=6)$ showed clinically relevant symptoms of anxiety than of depression $(21.4 \%, \mathrm{~N}=3)$. No significant differences were found in DSS scores between patients with and without clinically relevant affective symptoms. An interesting question is whether OD complaints could be caused by an affective state. One theory is drawn from the bladder-gut-brain axis, which is a bidirectional pathway between brain and body. According to that theory, functional disorders and somatic symptoms are sensitized responses to earlier threats (alarm falsification). MUNOD could be such false-alarm behavior. In patients with prolonged unexplained complaints of $O D$, psychiatric conditions must be considered as a possible cause and a psychiatrist should be involved.

\section{Medically unexplained otorhinolaryngology symptoms}

Medically unexplained symptoms are seen not only in patients with OD but also in many other patients at the otorhinolaryngological (ORL) outpatient clinic. Medically unexplained otorhinolaryngology symptoms (MUORLS) are associated with increased healthcare costs, risk of iatrogenic damage, and frustration among patients and 
healthcare workers. A psychiatric disorder might be the underlying cause and its identification is often delayed, partly due to the somatic focus of the physician and the patient.

Chapter 6 investigated patients with MUORLS and proposed an integrated multidisciplinary approach that would involve consulting a psychiatrist. In total 102 patients with ORL complaints were included. Their most common complaints were dizziness, pharyngeal globus, OD, dysphonia, and nasal obstruction. All patients had subjective complaints that showed a discrepancy with the clinical examination (no ORL diagnosis or an ORL diagnosis that did not fit the complaints). Included patients had a joint interview with an otorhinolaryngologist and a psychiatrist at the ORL outpatient clinic. If indicated, patients were subsequently invited to visit the hospital psychiatry outpatient clinic. Of all included patients, 78\% $(\mathrm{N}=80)$ appeared to have a psychiatric diagnosis according to the Diagnostic and Statistical Manual of Mental Disorders Fourth Edition (DSM-4-TR). Psychiatric diagnosis was often delayed by additional examinations that were performed to exclude somatic disorders. Many patients visited the outpatient clinic on numerous occasions (up to 92 times). Thirty-two percent ( $N=32$ ) of the patients underwent some type of treatment for a somatic diagnosis without any improvement of their complaints. Thus, patients with MUORLS often suffered from psychiatric (co)morbidity, which probably contributed to their ORL complaints.

\section{General discussion}

Although psychological distress, including affective symptoms, is common in OD patients, this problem is often under-recognized. Eating and drinking are fundamental daily requirements and an important part of social interaction. OD patients often are ashamed and have decreased social activities, implying that swallowing problems have an effect on psychological well-being. The severity of OD does not seem to be a good indicator for the presence of clinically relevant affective symptoms, which underscores the complexity of the problem. In addition, patients with medically unexplained symptoms, who constitute a challenging category of patients, often suffer from clinically relevant affective symptoms. An interesting theory in this matter is drawn from the bladder-gut-brain axis, which states that body and brain are interconnected and that psychiatric disorders, but also early stages of a somatic disease, might coincidentally induce psychological and somatic symptoms. This behavior of alarm falsification within the body's defense system may worsen the somatic symptoms in OD patients with an underlying somatic disease, but it might also cause medically unexplained symptoms. There is increasing evidence that psychological and somatic symptoms are interconnected. Patients with both somatic and psychological symptoms may benefit from an interdisciplinary approach that includes mental healthcare. It is assumed that integrated care makes it easier to discuss psychological distress and gets patients motivated for referral to psychological and psychiatric care. The studies described in this thesis had a cross-sectional design, meaning no causal relationship 
between affective symptoms and OD could be demonstrated. Therefore, to better understand the nature and direction of the relationship between psychiatric symptoms and $O D$, longitudinal cohort studies should be conducted in the future. 

Samenvatting 



\section{Samenvatting}

Dit proefschrift bevat studies naar affectieve symptomen bij patiënten met orofaryngeale dysfagie (OD), en kan worden verdeeld in twee secties; hoofdstukken 2, 3 , en 4 hebben betrekking op affectieve symptomen bij patiënten met OD, bij wie er sprake is van een onderliggende somatische ziekte of aandoening. Hoofdstuk 5 en 6 hebben betrekking op patiënten met medisch onbegrepen klachten.

\section{Prevalentie van angst- en depressieve symptomen bij patiënten met OD}

Bij patiënten met een somatische ziekte of aandoening is er vaak sprake van psychische problemen. Zo worden bijvoorbeeld affectieve symptomen vaak gezien bij patiënten met cardiale problemen, patiënten met chronisch obstructieve longziekten (COPD) of patiënten met suikerziekte. De prevalentie van affectieve symptomen is afhankelijk van de etiologie van het somatische ziektebeeld. Voorafgaand aan dit proefschrift was er slechts weinig bekend over affectieve symptomen en psychiatrische co-morbiditeit bij patiënten met OD. Echter, deze patiënten maakten tijdens hun poliklinische bezoeken vaak een depressieve indruk of gedroegen zich angstig tijdens het slikonderzoek.

Het doel van de eerste studie uit dit proefschrift (hoofdstuk 2) was om de prevalentie van angst- en depressieve symptomen (affectieve symptomen) bij patiënten met $O D$, die zich op de dysfagie polikliniek presenteerden, vast te stellen. Zesennegentig patiënten met OD, zoals vastgesteld door middel van Fiberoptic Endoscopic Evaluation of Swallowing (FEES) en Videofluoroscopisch Slikonderzoek (VFS), werden geïncludeerd. Alle patiënten hadden een onderliggende somatische ziekte als verklaring voor de OD (ziekte van Parkinson, hoofd-halskanker, myotone dystrofie, etc.). Voor het meten van klinisch relevante angst- en depressieve symptomen werd in deze studie gebruik gemaakt van de Hospital Anxiety and Depression Scale (HADS). Deze gevalideerde vragenlijst bestaat uit 14 onderdelen; 7 vragen hebben betrekking op angstsymptomen (angst subschaal) en 7 vragen op depressieve symptomen (depressie subschaal). Aan iedere vraag kunnen 0 tot 3 punten worden toegekend. De totale score ligt dan tussen de 0 en 21 punten voor beide subschalen. Klinisch relevante angst- of depressieve symptomen zijn gedefinieerd als een score van 8 of hoger of een van de beide subschalen. Ook werd bij patiënten de Dysphagia Severity Scale (DSS) afgenomen. Deze visueel analoge schaal (VAS) is een makkelijke en subjectieve beoordeling van de actuele slikfunctie door de patiënt zelf. Een lage DSS-score betekent dat de patiënt de slikfunctie als slecht beoordeelt. Een hoge DSS-score betekent dat de patiënt de slikfunctie als goed beoordeelt. Deze studie toont een hoge prevalentie ( $N=43 ; 47.3 \%)$ van klinisch relevante affectieve symptomen hetgeen overeenkomt met andere poliklinische patiënten populaties. Patiënten met klinisch relevante angstsymptomen hadden een lagere DSS-score in vergelijking met patiënten zonder angstsymptomen. Dit kan betekenen dat ofwel angstsymptomen leiden tot meer subjectieve klachten van OD ofwel klachten van OD een risicofactor zijn voor klinisch relevante angstsymptomen. $\mathrm{Er}$ 
werd geen verband gevonden tussen de DSS-score en klinisch relevante depressieve symptomen.

\section{Ernst van OD en affectieve symptomen}

Zoals hierboven besproken komen affectieve symptomen vaak voor bij patiënten met $O D$. Onze verwachting was dat patiënten met ernstige $O D$ een hoger risico zouden hebben op affectieve symptomen in vergelijking met patiënten met een milde OD.

In hoofdstuk 3 onderzochten wij of er een verband bestaat tussen de ernst van de OD en het hebben van affectieve symptomen. Er werden in totaal 107 patiënten met OD geïncludeerd in deze studie. Alle geïncludeerde patiënten waren gediagnosticeerd met een onderliggende somatische ziekte of aandoening en ondergingen een gestandaardiseerd FEES-onderzoek. De ernst van de OD werd bepaald aan de hand van 4 visuoperceptieve FEES-variabelen welke werden beoordeeld door twee onafhankelijke en geblindeerde beoordelaars. Voor het meten van klinisch relevante angst- en depressieve symptomen werd de HADS-vragenlijst gebruikt. De DSS werd gebruikt als subjectieve beoordeling van de slikfunctie door de patiënt zelf. Deze studie toont geen positieve correlatie tussen affectieve symptomen en de ernst van de OD. Blijkbaar kunnen affectieve symptomen bij dysfagie-patiënten niet worden voorspeld aan de hand van de ernst van OD zoals gemeten met FEES. Ook werd geen correlatie gevonden tussen de DSS-score en de verschillende FEES-variabelen. Er blijkt dus geen verband te zijn tussen de ernst van de OD en de subjectieve beoordeling van de slikfunctie door de patiënt zelf. Een toenemend verlies van sensorische functie en daardoor een minder nauwkeurige waarneming van slikproblemen zou een verklaring hiervoor kunnen zijn. In hoofdstuk $\mathbf{2}$ werd wel associatie gevonden tussen de DSS-score en klinisch relevante angstsymptomen. Wellicht hebben angstsymptomen (en mogelijk ook depressieve symptomen) invloed op de 'slikperceptie' en is er bijvoorbeeld een overschatting van het slikprobleem.

\section{Evaluatie van affectieve symptomen bij OD}

Hoofdstuk 4 bevat een systematische literatuur review en geeft een overzicht van de gepubliceerde literatuur over angst- en depressieve symptomen bij patiënten met OD. $\mathrm{Na}$ een gestructureerd database onderzoek in Embase, Medline, Web-of-Science, PsychINFO, Cochrane Library en Google scholar werden 24 artikelen geïncludeerd voor beoordeling. De geïncludeerde studies werden beoordeeld op methodologische kwaliteit door twee onafhankelijke beoordelaars met behulp van een 12-punts kritisch beoordelingsinstrument voor de evaluatie van de interne en externe validiteit. Geen van de geïncludeerde studies voldeed aan alle criteria voor methodologische kwaliteit. Vanwege de methodologische beperkingen en de heterogene uitkomstmaten kon de data van de verschillende studies niet worden samengevoegd. Ondanks het feit dat er geen meta-analyse kon worden verricht, werden wel enkele trends gezien. Alle 24 studies concludeerden dat depressieve symptomen positief geassocieerd zijn met OD. 
Negen van de 12 studies waarbij werd gekeken naar angstsymptomen concludeerden dat angstsymptomen positief zijn geassocieerd met OD. Echter, een causaal verband tussen affectieve symptomen en OD kon niet worden aangetoond. Longitudinaal cohortonderzoek is nodig om het verband tussen $O D$ en affectieve symptomen beter te begrijpen. Er dient dan gebruik gemaakt te worden van gestandaardiseerde meetinstrumenten om OD te beoordelen. Ook dient bij voorkeur psychiatrisch onderzoek te worden verricht door een psychiater in plaats van vragenlijsten voor de screening naar affectieve symptomen. Slechts 5 studies gebruikten FEES of VFS om OD te meten en in slechts 1 studie (onze eigen studie, hoofdstuk 3) werden de uitkomstvariabelen voor FEES en VFS beschreven.

\section{Medisch onbegrepen klachten van OD}

Soms hebben patiënten klachten van OD zonder aantoonbare afwijkingen van de anatomie van de bovenste aerodigestieve tractus en/of aantoonbare afwijkingen van de slikfysiologie. Deze medisch onbegrepen orofaryngeale dysfagie (MUNOD) is een ingewikkeld probleem voor zorgverleners.

In de studie van hoofdstuk 5 werd bij 14 patiënten met MUNOD onderzocht of er sprake was van klinisch relevante affectieve symptomen. De HADS werd gebruikt om klinisch relevante angst- en depressieve symptomen te meten en de DSS werd gebruikt voor de subjectieve beoordeling van de slikfunctie door de patiënt zelf. De geïncludeerde patiënten hadden geen structurele afwijkingen of ernstige slikproblemen tijdens FEES-onderzoek. Vijf visuoperceptieve FEES-variabelen werden beoordeeld door twee onafhankelijke beoordelaars. De meeste patiënten hadden een afwijkende variabele 'piecemeal deglutition' (het aantal slikacts dat de patiënt nodig heeft om 1 bolus te verwerken). Een afwijkende 'piecemeal deglutition' zou een symptoom van MUNOD kunnen zijn, aangezien meerdere slikacts van kleinere porties van eenzelfde bolus een gevoel van zekerheid en controle kunnen geven. Tweeënveertig procent $(\mathrm{N}=6)$ van de patiënten had klinisch relevante angstsymptomen en $21.3 \%(\mathrm{~N}=3)$ van de patiënten had klinisch relevante depressieve symptomen. Er waren geen significante verschillen in DSS-scores tussen patiënten met en zonder affectieve symptomen. Zou OD veroorzaakt kunnen worden door een affectieve stoornis? Eén theorie is de 'bladder-gut-brain-axis'; een bi-directioneel pathway tussen lichaam en brein. Deze theorie stelt dat functionele aandoeningen en somatische symptomen, en de daarbij behorende affectieve problemen, het resultaat zijn van een gesensitiseerde respons op eerdere bedreigingen die de patiënt heeft ervaren ('vals alarm' of 'alarmfalsificatie'). MUNOD kan een dergelijk symptoom zijn. Bij patiënten met aanhoudende onbegrepen klachten van OD moet een onderliggende psychiatrische aandoening als oorzaak van deze klachten worden overwogen en een psychiater worden betrokken in de zorg. 


\section{Medisch onbegrepen keel-, neus- en oorklachten}

Medisch onbegrepen klachten worden niet alleen gezien bij patiënten met OD maar ook bij veel andere patiënten op de polikliniek Keel-, Neus- en Oorheelkunde (KNO). Medisch onbegrepen KNO-klachten (MUORLS) zijn geassocieerd met hogere zorgkosten, risico op iatrogeen letsel en frustratie tussen patiënt en zorgverleners. Een psychiatrisch ziektebeeld kan de onderliggende oorzaak zijn echter wordt dit meestal pas laat herkend doordat zorgverleners en patiënten zich focussen op de somatiek.

In de studie van Hoofdstuk 6 werden patiënten met MUORLS integraal multidisciplinair benaderd inclusief een beoordeling door een psychiater. In totaal werden 102 patiënten met MUORLS geïncludeerd. De meest voorkomende klachten waren duizeligheid, globusgevoel, OD, dysfonie en nasale obstructie. Alle patiënten hadden subjectieve klachten die niet in verhouding stonden met het klinisch onderzoek (geen KNO-diagnose of een KNO-diagnose die niet paste bij de klachten). Patiënten werden gezien op de polikliniek KNO in een gezamenlijk consult met een KNO-arts en een psychiater. Indien geïndiceerd, kregen patiënten een uitnodiging op de polikliniek psychiatrie. Van alle geïncludeerde patiënten bleek $78 \%(\mathrm{~N}=80)$ een psychiatrisch ziektebeeld te hebben. Deze diagnose werd vaak vertraagd door herhaaldelijk en veelvuldig onderzoek om een somatische aandoening uit te sluiten. Veel patiënten bezochten de polikliniek veelvuldig (tot wel 92 keer). Tweeëndertig procent $(\mathrm{N}=32)$ van de patiënten onderging een somatische behandeling zonder verbetering van de klachten. Patiënten met MUORLS hebben vaak psychiatrische (co)morbiditeit welke waarschijnlijk bijdraagt aan hun KNO-klachten.

\section{Algemene discussie}

Ondanks dat een groot deel van de patiënten met OD last heeft van affectieve symptomen wordt dit probleem vaak niet herkend. Eten en drinken behoren tot de primaire levensbehoeften en zijn daarnaast een belangrijk onderdeel van sociale interactie. Patiënten met OD schamen zich vaak en hebben daardoor minder sociale activiteiten. Een verminderde slikfunctie heeft daardoor effect op het psychosociale welbevinden van de patiënt. De ernst van OD lijkt geen goede voorspeller te zijn voor het al dan niet aanwezig zijn van affectieve symptomen, wat de complexiteit van dit probleem alleen maar meer onderstreept. Ook patiënten met medisch onbegrepen $O D$, een uitdagende patiëntencategorie, hebben vaak last van affectieve symptomen. Een interessante theorie hierbij is de 'bladder-gut-brain axis', die stelt dat lichaam en brein verbonden zijn en psychiatrische ziekten, maar ook somatische aandoeningen, psychologische en somatische symptomen kunnen veroorzaken. Dit 'vals alarm' afweersysteem kan somatische symptomen bij patiënten met een somatisch verklaarde $O D$ verergeren en medisch onbegrepen symptomen veroorzaken. Steeds meer literatuur suggereert dat psychologische en somatische symptomen elkaar beïnvloeden. Patiënten met somatische symptomen en psychologische co-morbiditeit kunnen voordeel hebben van een interdisciplinaire benadering inclusief een psychiater 
of psycholoog. Tijdens integrale zorg kunnen psychologische problemen makkelijker bespreekbaar worden gemaakt en kunnen patiënten eerder gemotiveerd zijn om verwezen te worden voor psychologische of psychiatrische hulp. Aangezien de studies in dit proefschrift cross-sectionele onderzoeken zijn, kon geen causaal verband tussen affectieve symptomen en OD worden aangetoond. Toekomstige longitudinale cohortstudies zijn nodig om de aard en de richting van de relatie tussen psychiatrische symptomen en OD te bepalen. 
